\title{
Marie Dejoux
}

Gouvernement et pénitence

Les enquêtes de réparation des usures juives de Louis IX (1247-1270)

En 1247, avant la croisade, et jusqu'à sa mort en 1270, Louis IX fit recueillir les plaintes de ses sujets afin de réparer les torts de son administration. Pénitentielles, ces enquêtes étaient aussi des instruments de gouvernement, comme en attestent les enquêtes de restitution des usures juives. Les saisies générales des biens des créanciers juifs avaient rendu Louis IX coupable d'un recel d'autant plus peccamineux qu'il provenait d'une activité condamnée par l'Église et par le roi en personne: l'usure. Au nom de sa souveraineté sur ses juifs - les «juifs du roi »- et pour le salut de son âme, le roi entendit publiquement rendre à ses sujets ces biens mal acquis. La restitution des usures juives est une entreprise de conversion multiple: Louis IX ne restitue qu'une partie des biens des juifs et convertit le reste à un usage pieux, la croisade. En rendant, il transforme également en salut ses exactions et tourne à son avantage le rejet que pouvaient inspirer les créanciers juifs. Ces enquêtes incarnent donc un art de gouverner singulier, mêlant contrainte et consentement, souveraineté et scrupule religieux: le «moment saint Louis".

\section{Government and Penance: Louis IX's Restitution of Jewish Usury (1247-1270)}

Between his first crusade in 1247 and his death in 1270, Louis IX decided to collect his subjects' grievances in order to right the wrongs of his administration. A penitential act, the inspections that ensued were also instruments of government: the king aimed to both save his soul and to rule his kingdom. This dual purpose is particularly apparent in the investigations into the restitution of Jewish wealth acquired through usury. By seizing the property of Jewish creditors, Louis IX was guilty of retaining the profits of an activity condemned by both the church and himself: usury. To assert his sovereignty over his Jews - the "Jews of the King" - and for the salvation of his soul, the king intended to publicly return these ill-gotten gains to his subjects. These restitutions entailed multiple conversions: Louis IX only returned a portion of the goods that had been appropriated by Jews, converting the rest into funds for the crusade. In doing so, the king also converted his wrongs into salvation, and turned the revulsion that Jewish creditors could inspire to his advantage. These investigations thus embodied a singular art of government, combining coercion and consent, sovereignty and religious scruple: the "Saint Louis moment." 


\section{Maurice Kriegel}

L'esprit tue aussi

Juifs « textuels» et Juifs « réels » dans l'histoire

Dans son livre, David Nirenberg donne de l'antijudaïsme une définition très englobante : il ne s'agit pas de l'hostilité à l'égard d'une religion, d'une culture ou d'une population - le judaïsme et les Juifs -, mais de l'appréhension critique d'un ensemble de notions que représente le "judaïsme", à travers laquelle les porteurs de cet antijudaïsme cherchent à se situer dans le monde et à donner sens à leur action. Pour D. Nirenberg, cet antijudaïsme a constitué l'un des principaux outils à l'aide desquels l'édifice de la pensée occidentale a été construit; il s'est nourri des débats internes au christianisme d'abord, à la culture européenne ensuite, sans confrontation directe avec les Juifs; et l'antisémitisme correspond au cas particulier dans lequel le discours de l'antijudaïsme est appliqué aux Juifs concrets. Cet article, qui discute ces thèses, se propose deux objectifs : calibrer autrement la part de la tradition de l'antijudaïsme dans l'institution des discours et de l'imaginaire " occidentaux"; souligner qu'à chaque étape - dans l'Antiquité tardive, au Moyen Âge et au début des temps modernes, depuis les Lumières - l'évolution des attitudes envers les Juifs est d'abord fonction de changements dans les rapports qu'entretient la société majoritaire avec les Juifs réels.

\section{The Spirit Kills as Well: "Textual" Jews and "Real" Jews in History}

In his book, David Nirenberg defines "anti-Judaism" in a very broad way: it is, he says, not simply "an attitude toward Jews and their religion, but a way of critically engaging the world." For Nirenberg, anti-Judaism, understood in this way, has been one of the main tools used to construct the edifice of Western thought: it initially developed out of debates within Christianity, then European culture more generally, with little direct contact with actual Jews (anti-Semitism describes the particular cases where this discourse of antiJudaism is applied to real Jewish communities). The aim of this article is twofold: it proposes an alternative reading of the part played by anti-Judaism in the elaboration of the discourses and the imagination of "the West," and it insists that at each stage—in late Antiquity, during the Middle Ages and the early modern period, from the Enlightenment onwards - the transformation of attitudes towards Jews is due first and foremost to changes in the relations between the majority society and real Jews.

\section{Steven Englund}

\section{De l'antijudaïsme à l'antisémitisme, et à rebours}

Le paradigme actuellement dominant dans les recherches sur l'antisémitisme correspond à la vision proposée dans l'Encyclopaedia Britannica (1910) : «L'antisémitisme est une question exclusivement politique et européenne. » Si cette conception a donné lieu à des études empiriques majeures, elle recèle des problèmes conceptuels, dont le moindre n'est pas qu'elle se contente de recycler l'idée que les antisémites se font d'eux-mêmes, à savoir que leur préoccupation n'est pas religieuse mais liée à des considérations objectives. Le présent article démontre en quoi les discours déployés et l'attrait politique de l'antisémitisme doivent être distingués de sa réception et de sa compréhension sociale; il suggère que le «nouvel» Antisemitismus, tel qu'il a été compris dans les faits, est d'une nature différente de ce qui avait été l'intention de ses partisans. Ce soi-disant «nouvel antisémitisme» implique l'influence omniprésente, forte et néanmoins subtile d'une ancienne trinité d'éléments "spirituels» 
sous-jacents : la religion institutionnalisée (Olaf Blaschke); le religieux dans un sens diffus, ou «métabolisé» (Marcel Gauchet); la religiosité comme posture personnelle, qui guide les antisémites en tant qu'individus (Gavin Langmuir). Ces dimensions ont imprégné les positions et les désaccords d'un antisémitisme ordinaire agissant sur le plan politique, social, économique, culturel et «racial». Elles véhiculent son message, jusque dans les strates intellectuelles et émotionnelles les plus profondes, auprès de populations qui ont baigné dans l'antijudaïsme pendant des siècles (David Nirenberg). D. Nirenberg ayant analysé l'imaginaire social de l'antijudaïsme, il reste à voir où et comment il rejoint et sous-tend discrètement l'antisémitisme politique.

\section{From Anti-Judaism to Antisemitism—and Back Again?}

The current paradigm prevailing in the study of antisemitism is the view proposed in The Encyclopaedia Britannica (1910): “Antisemitism is exclusively a question of European politics." This approach has afforded important empirical studies, but it contains conceptual problems, not least that it recycles the antisemites' view of themselves: that is, that they were not concerned with religion but objective issues. This article argues that discursive deployment and political appeal are not the same as social reception and understanding; it proposes that the ways in which the "new" Antisemitismus was actually heard constituted a different matter from what its proponents intended. In the so-called "new antisemitism," we encounter the omnipresent, strong, but subtle influence of an old trinity of unstated "spiritual" elements: institutional religion (Olaf Blaschke); le religieux in the diffuse, or "metabolized," sense (Marcel Gauchet); rogue religiosity, in the motives of individual antisemites (Gavin Langmuir). These dimensions may be shown to have suffused the statements and conflicts of "ordinary" political, social, economic, cultural, and "racial" antisemitism. They carried its message to the intellectual and emotional levels in populations that had been bathed in antijudaism for centuries (David Nirenberg). As Nirenberg has analyzed the social imaginary of antijudaism, the question of where and how it joins and quietly underlies political antisemitism must now be posed.

\section{José Javier Ruiz lbanez}

Les acteurs de l'hégémonie hispanique, du monde à la péninsule Ibérique

La compréhension de la formation et de l'hégémonie de la Monarchie espagnole aux XVI ${ }^{\mathrm{e}}$ et XVII ${ }^{\mathrm{e}}$ siècles ne peut pas se faire sans l'étude des phénomènes sociaux et culturels sur lesquels elle s'est établie. L'expansion du pouvoir espagnol et portugais a déclenché des processus politiques et sociaux qui ont eu comme protagonistes les populations locales d'Europe, d'Afrique, d'Asie et des Amériques. Bien qu'elles aient été incorporées, de gré ou de force, ou qu'elles aient été voisines du pouvoir ibérique, leurs tensions locales et leurs choix politiques ont fini par devenir décisifs dans la configuration du pouvoir espagnol et son évolution. La politique locale devient ainsi un objet d'analyse du global. L'histoire de la Monarchie incorpore les processus violents de sa formation, son polycentrisme, ses rapports avec le reste du monde et, surtout, met au premier plan les acteurs ordinaires: ceux qui l'ont adoptée et ceux qui l'ont combattue.

\section{The Actors of the Spanish Hegemony: From the World to the Iberian Peninsula}

The formation and the hegemony of the Spanish monarchy in the sixteenth and seventeenth centuries cannot be understood without studying the diverse social and cultural phenomena 
that lie at its foundations. The expansion of Spanish and Portuguese power unleashed certain political and social processes in which the local populations of Europe, Africa, Asia and the Americas were the main actors. Whether these populations were incorporated by consent or through force, or whether they were neighbors to Iberian power, their local tensions and their electoral choices became decisive in the eventual configuration of Spanish power and its evolution. The analysis of local politics thus becomes key to an understanding of events on a global scale. The history of the Spanish monarchy incorporates the violent process of its formation, its polycentrism, its relationship with the rest of the world, and, especially, the importance of ordinary actors: those that accepted it or those that fought against it.

\section{Carole Ferret}

Discontinuités spatiales et pastoralisme nomade en Asie intérieure au tournant des $X I X^{e}$ et $X X^{e}$ siècles

Le pastoralisme, activité traditionnelle des peuples turco-mongols de Sibérie et d'Asie centrale, a créé des discontinuités qui ont structuré l'espace apparemment homogène de la steppe. Par leurs parcours de nomadisation stables et réguliers, les éleveurs découpent l'espace en pâtures saisonnières, appréciant la qualité des terres en fonction des besoins du bétail et relativement à une saison donnée. L'analyse du fonctionnement des diverses formes de pastoralisme nomade pratiquées au tournant des XIX ${ }^{\mathrm{e}}$ et XX $\mathrm{XX}^{\mathrm{e}}$ siècles par les Turkmènes, les Kazakhs, les Kirghizes, les Khakasses, les Bouriates, les Touvas, les Mongols et les Iakoutes permet d'affiner ce modèle et d'identifier plusieurs types de nomadisme, suivant des critères fondés sur le mode de résidence, la forme des parcours, la fréquence et l'amplitude des nomadisations. Interrogeant plusieurs idées reçues, l'auteur montre que, si le bétail est bien le moteur du nomadisme, il n'existe pas de corrélation univoque, synchronique ni diachronique, entre le degré de mobilité des hommes et celui des espèces élevées. Pastoralisme et nomadisme sont deux phénomènes liés, mais ils ne peuvent être confondus.

Spatial Discontinuities and Nomadic Pastoralism in Inner Asia at the Turn of the Nineteenth and Twentieth Centuries

Pastoralism, the traditional activity of Turkic-Mongol peoples in Siberia and Central Asia, has created structural discontinuities in the apparently homogeneous steppe area. Through their stable and regular nomadic routes, herdsmen divide the space into seasonal pastures, assessing the quality of lands according to the needs of livestock in a given season. The analysis of various forms of nomadic pastoralism practiced at the turn of the nineteenth and twentieth centuries by Turkmens, Kazakhs, Kyrgyz, Khakas, Buryats, Tuvans, Mongolians and Yakuts, refines this model and identifies several types of nomadism, based on the residential patterns, the form of routes, and the frequency and amplitude of movements. Questioning several received ideas about nomadic pastoralism, the author shows that, although livestock is the main impulse of nomadism, there is no direct and unambiguous correlation (whether synchronic or diachronic) between the mobility of people and that of livestock. Pastoralism and nomadism are thus shown to be connected but distinct phenomena. 